\title{
The inhibition of microRNAs by HIV-1 Tat suppresses beta catenin activity in astrocytes
}

\author{
Luca Sardo $^{\dagger}$, Priyal R. Vakil ${ }^{\dagger}$, Weam Elbezanti, Anas El-Sayed and Zachary Klase*
}

\begin{abstract}
Background: Long term infection with HIV-1, even in the context of therapy, leads to chronic health problems including an array of neurocognitive dysfunctions. The viral Tat protein has previously been implicated in neuropathogenesis through its effect on astrocytes. Tat has also been shown to inhibit the biogenesis of miRNAs by inhibiting the activity of the cellular Dicer protein in an RNA dependent fashion. Whether there is a mechanistic connection between the ability of HIV-1 Tat to alter miRNAs and its observed effects on cells of the central nervous system has not been well examined.

Results: Here, we examined the ability of HIV-1 Tat to bind to and inhibit the production of over 300 cellular miRNAs. We found that the Tat protein only binds to and inhibits a fraction of the total cellular miRNAs. By mapping the downstream targets of these miRNAs we have determined a possible role for Tat alterations of miRNAs in the development of neuropathogenesis. Specifically, this work points to suppression of miRNAs function as the mechanism for Tat suppression of $\beta$-catenin activity.

Conclusions: The discovery that HIV-1 Tat inhibits only a fraction of miRNAs opens new areas of research regarding changes in cellular pathways through suppression of RNA interference. Our initial analysis strongly suggests that these pathways may contribute to HIV-1 disruption of the central nervous system.
\end{abstract}

Keywords: HIV-1, Tat, miRNA, Beta-catenin, Astrocyte, HAND

\section{Background}

Acquired immunodeficiency syndrome (AIDS) is a complex and multifaceted disease that arises from the infection of CD4+ T-cells by the human immunodeficiency virus (HIV-1). Advances in HIV research have provided us with anti-retroviral drugs that target various viral enzymes like reverse transcriptase, protease and integrase. Although these anti-retroviral drugs control replication of the virus no permanent cure has yet been discovered. Viral replication is positively regulated by the interaction between the viral Tat protein and an RNA element called transactivation response (TAR) element. The Tat protein binds to the nascent TAR RNA and recruits positive elongation complex (pTEFb) that enhances the

\footnotetext{
*Correspondence: z.klase@usciences.edu

'Luca Sardo and Priyal R. Vakil contributed equally to this work Department of Biological Sciences, McNeil Science and Technology Center Room 273, University of the Sciences, 600 S 43rd Street, Philadelphia, PA 19104, USA
}

rate and efficiency of HIV-1 transcription. HIV-1 invades the central nervous system (CNS) within a few weeks of infection and sets the stage for potentially severe inflammatory events. Anti-retroviral drugs poorly penetrate the blood-brain barrier of the CNS allowing low level ongoing replication in the CNS that leads to moderate to severe HIV-associated dementia $[1,2]$. The overall spectrum of viral neuropathogenesis is collectively referred to as HIV-associated neurocognitive disorders (HAND). HIV-1 does not infect neurons, implying that HAND must be mediated in an indirect fashion. The HIV-1 Tat protein has been shown to cross the cell membrane and have an effect on bystander cells [3-6]. Furthermore, Tat has been implicated in neurological diseases [7-11] and specific mutations within Tat correlate with cladespecific differences in the prevalence of HAND [11-13]. Specifically, Tat exposure has been shown to contribute to dysfunction of the dopaminergic system, influence dopaminergic uptake kinetics and alter the expression of opiate neuropeptides and receptors [14-16]. Substantial 
evidence exists that these effects are exacerbated by exposure to opiate drugs [7, 17-19].

Studies have examined the interplay between Tat, infection of astrocytes and opiate drugs that affect brain function. However, none of the studies have examined the role of microRNA (miRNA) in the TatHAND axis. RNA interference (RNAi) is a regulatory mechanism found in plants, nematodes, protozoan, Drosophila, and mammalian cells [20-22]. Double stranded RNA is recognized by the RNAi machinery and is processed into small, 21 nucleotide small-interfering RNA (siRNA) which are capable of suppressing gene expression. Endogenously expressed RNA can be involved in RNAi through a pathway involving Drosha mediated cleavage of RNA stem-loops in the nucleus, followed by exportation to the cytoplasm by Exportin-5, and finally cleavage of this pre-miRNA by Dicer to generate a small RNA duplex, called miRNA [2328]. This miRNA guides the RNA-induced silencing complex (RISC) to a complementary, but not perfectly matching, region in the target mRNA. This association inhibits protein translation with minimal effect on the target mRNA [21, 29, 30].

Preliminary studies have shown that the viral Tat protein inhibits miRNA function [31], not by blocking RISC complex directly, but by binding to the Dicer protein that plays a role in the production of miRNA [32]. A follow up to these studies revealed that alteration of miRNA by Tat-Dicer complex occurs in an RNA-dependent manner [33]. As Tat inhibition of miRNA biogenesis is not due to direct suppression of Dicer, but through the binding of RNA, this opens the intriguing possibility that Tat may be selectively inhibiting specific miRNAs. In this paper, we examine the association of Tat with specific miRNAs and determine what cellular pathways are affected by Tat driven changes in miRNA expression.

Our findings suggest that HIV-1 Tat protein inhibits only a subset of miRNAs and leads to the observed phenotypic changes in astrocytes within the CNS in HIV-infected patients. Our identification of specific miRNAs that are tightly bound to Tat protein suggests downstream effects in $\mathrm{Wnt} / \beta$-catenin signaling pathway. $\mathrm{Wnt} / \beta$-catenin signaling is a large and complex pathway known to play a role in numerous cellular activities like cell differentiation, survival and proliferation. Knockdown studies have shown that $\beta$-catenin plays a role in repression of basal HIV-LTR transcription [34, 35]. As such, by repressing the rate and efficiency of HIV-1 transcription, $\beta$-catenin serves as a cellular restriction factor in the CNS. This work identifies a mechanism by which Tat protein represses $\beta$-catenin activity, thereby promoting neuroinflammatory activities in HIV-infected patients.

\section{Results and discussion} HIV-1 Tat binds to a specific subset of cellular microRNAs

Previous studies have shown that Tat interacts with Dicer only in the presence of RNA [33]. Here, we examined which miRNAs are capable of binding to Tat in vivo. In order to identify which miRNAs interact with Tat, we transfected flag-tagged wild-type Tat plasmid into HEK293T mammalian cells and immunoprecipitated using anti-flag antibody, isolated RNA and measured the expression of five miRNAs: let7a, miR16, miR17, miR138 and miR326 (Fig. 1). miR16, miR17 and miR138 showed Tat interaction while let7a and miR326 did not bind to Tat protein. When Tat was mutated at position K51A, a residue previously shown to be critical to Tat inhibition of Dicer activity, the interaction between Tat and miR17 and miR138 was lost [33]. Interestingly, the IP of Tat K41A, which is incapable of transactivating the HIV-1 LTR but still has ability to inhibit Dicer function, showed similar miRNA binding as wild-type Tat.

In order to expand our preliminary findings, we performed immunoprecipitation of flag-tagged wild-type Tat from 293T cells and measured association with 380 human miRNAs (Fig. 2). After making a present-absent call, the data was normalized on a per-array basis and the enrichment of miRNAs by Tat was graphed as the ratio of Tat-associated to the whole cell level of each miRNA. Out of 380 miRNAs measured, 68 miRNAs were found to have at least some interaction with Tat protein (Fig. 2a).

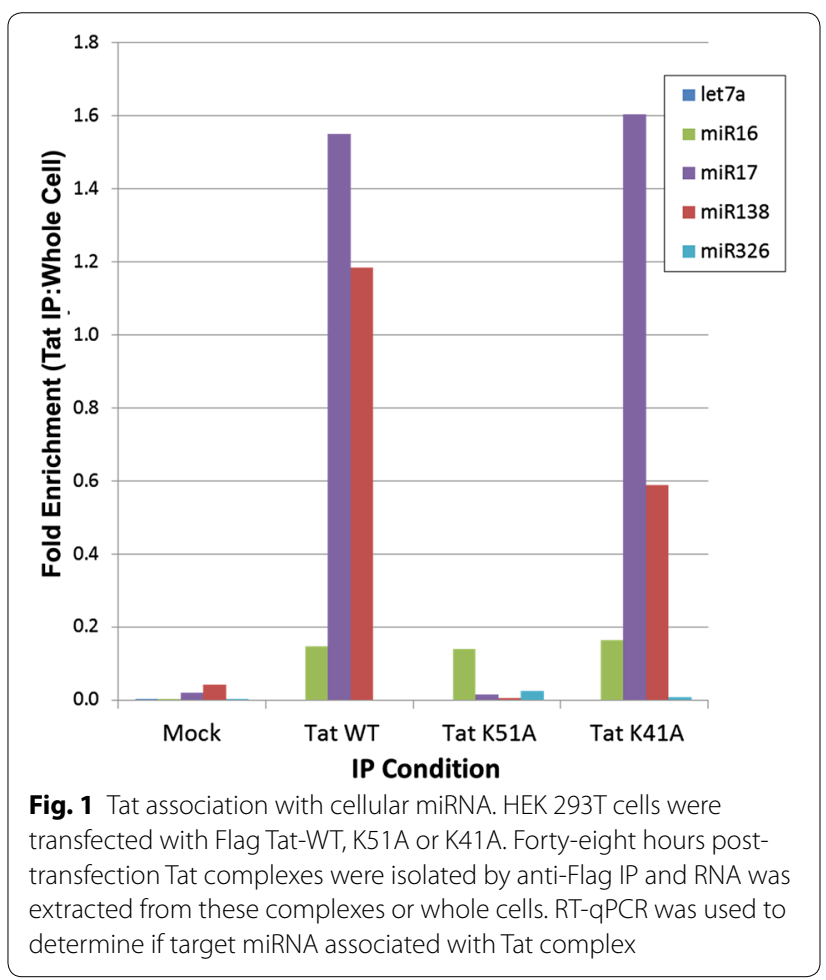




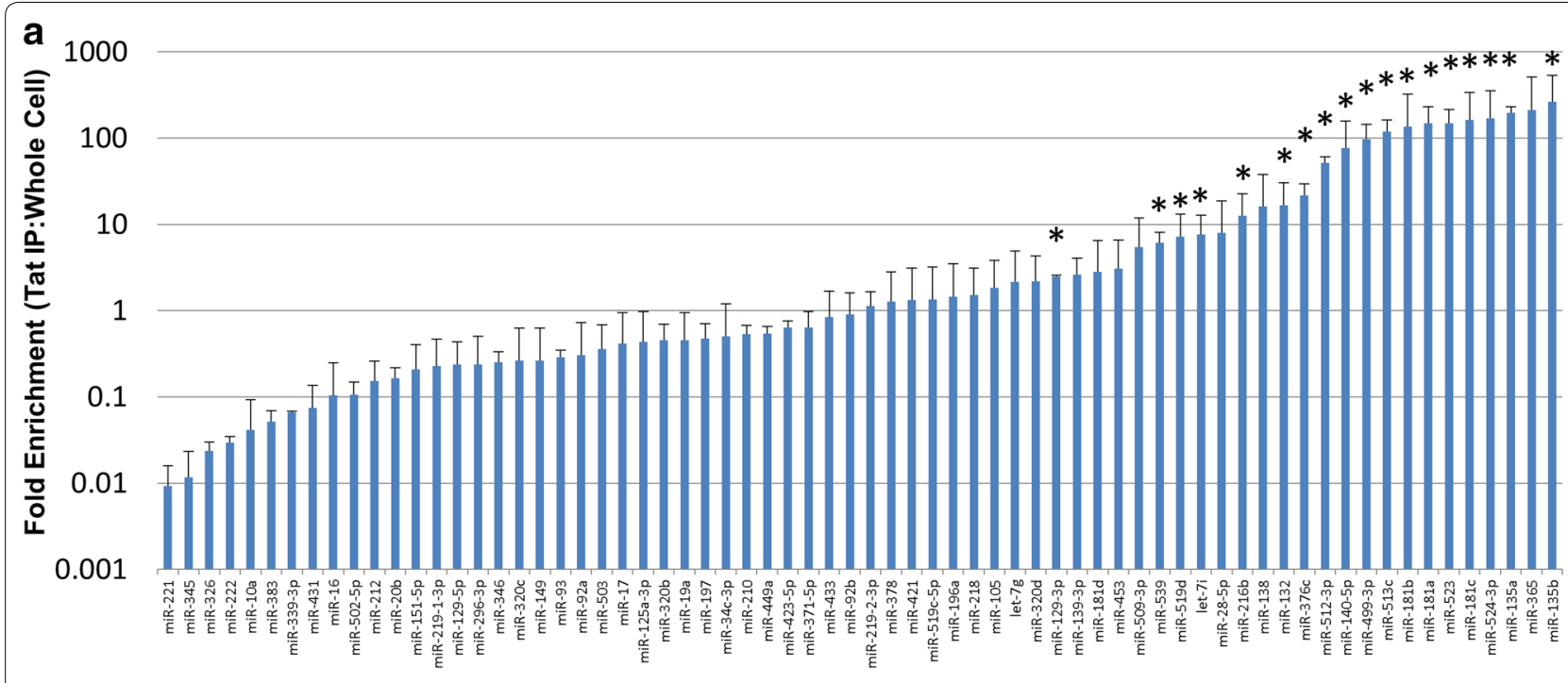

b 100

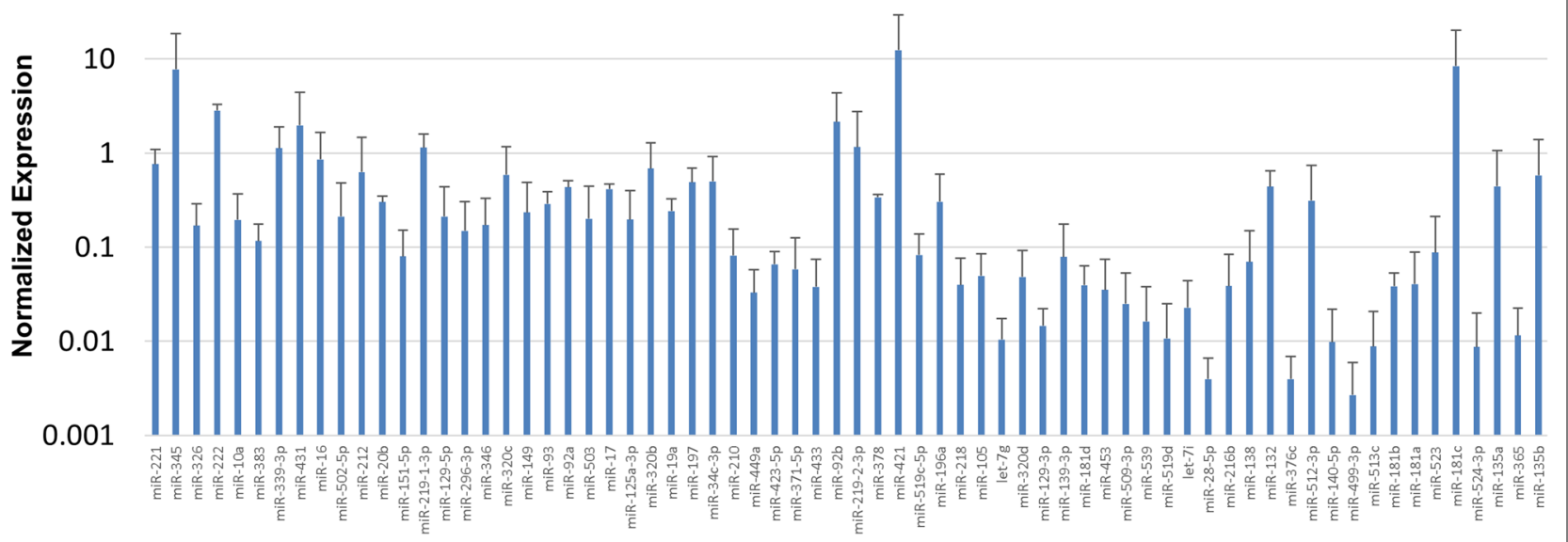

Fig. 2 Identification of miRNAs tightly bound by Tat complex. HEK 293T cells were transfected with Flag Tat plasmid and Tat complexes were isolated $48 \mathrm{~h}$ post-transfection using anti-Flag IP. a RNA from Tat complexes and whole cells was used as input into a polyA mediated RT-qPCR array capable of detecting over 300 human miRNAs. Shown is the fold enrichment in the Tat complex of the 68 miRNAs found to bind to Tat. The miRNAs indicated by asterisk show a twofold enrichment in the Tat complex as compared to the whole cell in all replicates. b Corresponding levels of miRNA in the whole cell RNA fraction

Of these 68 miRNAs bound to Tat, 18 miRNAs showed consistent enrichment of greater than twofold and were considered tight Tat binders (asterisk in Fig. 2a). On further analysis on these 18 miRNAs, ten miRNAs were found to be down regulated at the whole cell level when Tat protein was expressed (Table 1). To rule out the possibility that overall expression levels of a given miRNA were influencing the amount of miRNA measured in the Tat IP we graphed the whole cell levels of the 68 Tat associated miRNAs (Fig. 2b). No correlation was found between total expression levels and Tat binding. These results showed that Tat binds and inhibits the production of only a subset of possible miRNAs.

\section{HIV-1 Tat alters miRNAs with potential roles in the CNS}

Each individual miRNA is capable of potentially targeting dozens of mRNA transcripts and, depending on context and the number of targeting miRNA, have wide range of effect on protein expression. As such, we felt it was best to approach the issue of downstream effects in a holistic fashion that would look for the net outcome of changes in all of the 18 tight Tat binders. We employed ingenuity pathway analysis software (IPA) to predict the potential protein targets of the 18 tight Tat binders and then determine what pathways these proteins belong to. IPA analysis showed a strong probability of Tat alteration of miRNAs being involved in several processes 
Table 1 miRNAs associated with Tat protein

\begin{tabular}{|c|c|c|c|c|c|c|}
\hline miRNA & Fold enrichment & $\begin{array}{l}\text { Down } \\
\text { regulated? }\end{array}$ & $\beta$-Catenin & $\begin{array}{l}\text { Axonal } \\
\text { guidance }\end{array}$ & $\begin{array}{l}\text { Glucocorticoid } \\
\text { receptor signaling }\end{array}$ & $\begin{array}{l}\text { Nerve } \\
\text { growth factor }\end{array}$ \\
\hline let-7i & $7.6 \mathrm{E}+00$ & Yes & $x$ & $x$ & $x$ & $x$ \\
\hline miR-129-3p & $2.5 \mathrm{E}+00$ & Yes & $x$ & $x$ & $x$ & $x$ \\
\hline miR-132 & $1.7 \mathrm{E}+01$ & & & $x$ & $x$ & $x$ \\
\hline miR-135a & $2.0 \mathrm{E}+02$ & Yes & $x$ & $x$ & $x$ & $x$ \\
\hline miR-135b & $2.6 \mathrm{E}+02$ & Yes & $x$ & $x$ & $x$ & $x$ \\
\hline miR-140-5p & $7.6 \mathrm{E}+01$ & & $x$ & $x$ & $x$ & \\
\hline miR-181a & $1.5 \mathrm{E}+02$ & Yes & $x$ & $x$ & $x$ & $x$ \\
\hline miR-181b & $1.4 \mathrm{E}+02$ & Yes & $x$ & $x$ & $x$ & $x$ \\
\hline miR-181c & $1.6 \mathrm{E}+02$ & & $x$ & $x$ & $x$ & $x$ \\
\hline miR-216b & $1.3 \mathrm{E}+01$ & & $x$ & $x$ & $x$ & $x$ \\
\hline miR-376c & $2.2 \mathrm{E}+01$ & & $x$ & $x$ & $x$ & $x$ \\
\hline miR-499-3p & $9.6 \mathrm{E}+01$ & Yes & & $x$ & $x$ & $x$ \\
\hline miR-512-3p & $5.1 \mathrm{E}+01$ & & $x$ & & $x$ & \\
\hline miR-513c & $1.2 \mathrm{E}+02$ & & $x$ & $x$ & $x$ & \\
\hline miR-519d & $7.2 \mathrm{E}+00$ & & $x$ & $x$ & $x$ & $x$ \\
\hline miR-523 & $1.5 \mathrm{E}+02$ & Yes & & & & \\
\hline miR-524-3p & $1.7 \mathrm{E}+02$ & Yes & & $x$ & & \\
\hline miR-539 & $6.1 \mathrm{E}+00$ & Yes & $x$ & $x$ & X & $x$ \\
\hline
\end{tabular}

related to HIV-1 pathogenesis: Wnt/ $\beta$-catenin signaling cascade $\left(p=9.06 \times 10^{-9}\right.$, Fig. 3$)$, axonal guidance $\left(\mathrm{p}=5.92 \mathrm{E}^{-18}\right.$, Fig. 4), glucocorticoid receptor signaling $\left(\mathrm{p}=1.23 \times 10^{-11}\right.$, not shown $)$ and nerve growth factor signaling $\left(\mathrm{p}=1.3 \times 10^{-14}\right.$, not shown) [36-40]. Previous studies have shown that alterations of $\beta$-catenin in HIV-1 infected CNS is likely a necessary step for infection of astrocytes and eventual neuropathogenesis [38]. From our analysis, we show that Tat has a role in the neuropathogenesis of CNS by its suppression of specific miRNAs that are involved in $\mathrm{Wnt} / \beta$-catenin signaling or axonal guidance pathway.

\section{HIV-1 Tat downregulates $\beta$-catenin activity in a miRNA dependent manner}

Our IPA analysis suggested an effect on Wnt/ $\beta$-catenin signaling when wild-type Tat protein is expressed. To confirm an effect on beta-catenin and the involvement of miRNAs, we performed a $\beta$-catenin responsive reporter gene assay to look at the $\beta$-catenin activity in an astrocyte cell line, U-87MG (Fig. 5). Previous studies have shown that lithium chloride $(\mathrm{LiCl})$ enhances the activity of $\beta$-catenin in cells. Therefore, we performed luciferase assay with wild-type Tat in presence of $\mathrm{LiCl}$. Transfection of U-87MG with increasing amounts of wild-type Tat showed a dose dependent decrease in $\beta$-catenin activity when compared to just $\mathrm{LiCl}$ treatment (Fig. 5a). This is consistent with earlier reports that Tat is capable of inactivating $\beta$-catenin. Interestingly, when transfecting Tat K41A a significant decrease in $\beta$-catenin activity was not observed (Fig. 5b). A previous study has already identified lysine 41 as an important residue in $\beta$-catenin modulation [34]. The Tat K51A mutant, which is incapable of binding to miRNA, induces a slight, but statistically significant suppression of $\beta$-catenin activity. However the suppression of $\beta$-catenin activity by Tat K51A is significantly weaker than wild-type Tat. This new data confirms a role for lysine 51 and its ability to modulate miRNA interaction and suppression in the ability of Tat to suppress $\beta$-catenin activity.

To confirm that the identified miRNAs could mediate the downregulation of the $\beta$-catenin signaling pathway we used miRNA inhibitors (antagomirs) to block the effect of miRNAs. Antagomirs complementary to miRNAs predicted to target $\beta$-catenin were transfected into $\mathrm{U}-87 \mathrm{MG}$ along with a $\beta$-catenin responsive reporter gene (Fig. 6a). Inhibition of miR-135 and miR-181 induced a statistically significant reduction of $\beta$-catenin activity in U-87MG astrocytes. Blocking the effect of miR-539 and miR-129 had no effect. Interestingly, inhibition of let-7 induced a dose dependent increase in $\beta$-catenin activity. The reduction of $\beta$-catenin activity mediated by miR-181 was confirmed also in HeLa cells (Fig. 6b).

\section{HIV-1 Tat alters the morphology of U-87MG astrocyte cells}

When U-87MG was treated with $\mathrm{LiCl}$ we observed a striking change in morphology that correlated with the activity of $\beta$-catenin. Specifically, the cells appeared more spindle-like with significant branching when compared to the normal morphology of U-87MG (Additional file 1: 


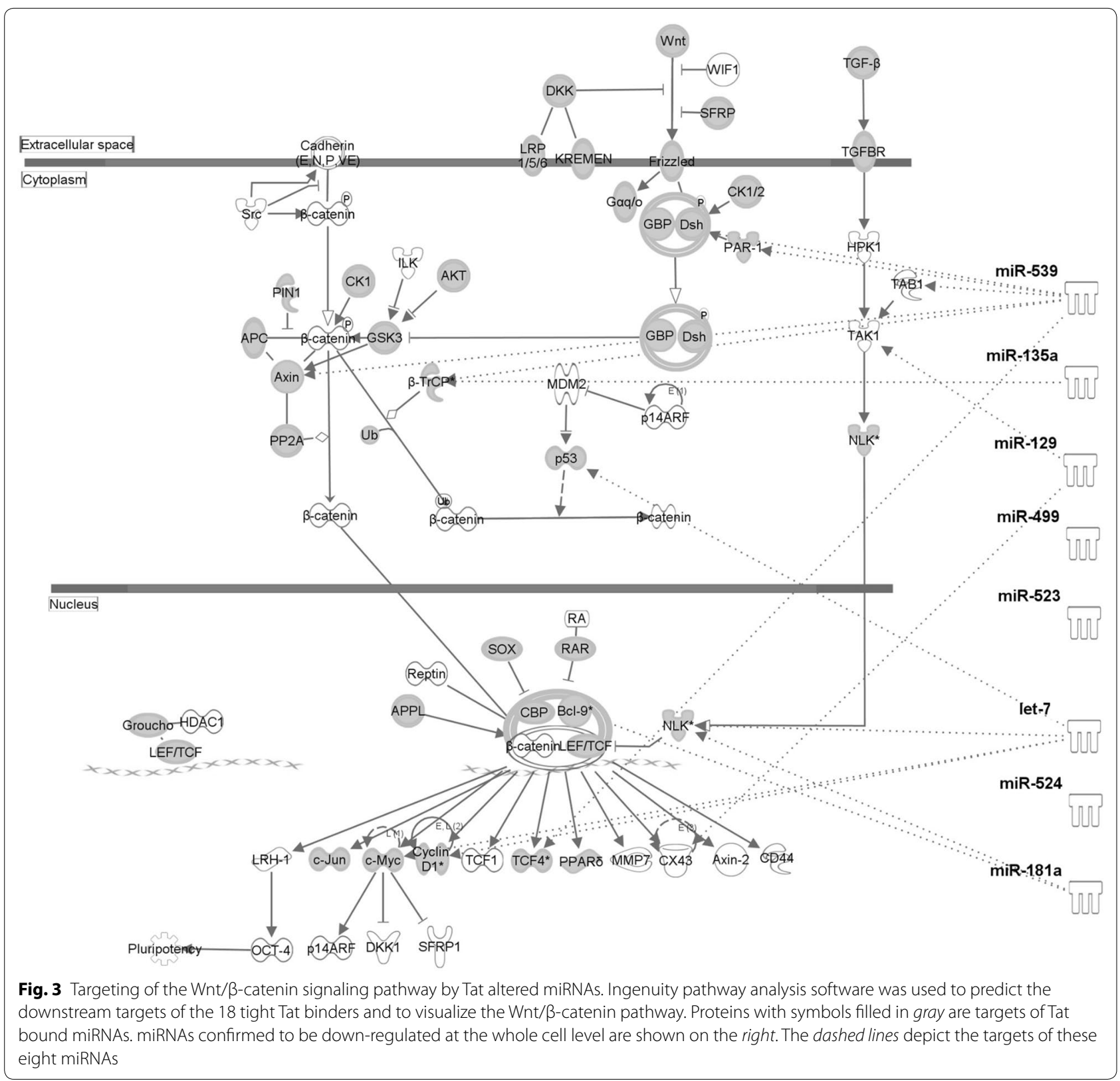

Figure S1). This morphology appears similar to protoplasmic astrocytes seen in brain tissue. However, when wild-type Tat was transfected into U-87MG prior to the introduction of $\mathrm{LiCl}$, the cells seemed to lose their spindle-like structure and appeared smaller, similar to the morphological changes observed in the brains of HIV-1 infected patients suffering from HAND.

\section{Conclusions}

It has been previously reported that HIV-1 Tat protein binds and inhibits Dicer in a RNA-dependent manner. In the current study, we show that Tat protein binds and inhibits the production of only certain cellular miRNAs. We identified 68 miRNAs that have some interaction with Tat protein. Out of these 68 miRNAs, we found that 18 showed more than twofold enrichment with Tat and were categorized as tight Tat binders. When the potential targets of these 18 tight Tat binders were analyzed, it was found that these miRNAs were likely involved in either axonal guidance, glioma signaling, glucocorticoid synthesis or canonical Wnt/ $\beta$-catenin signaling in the CNS. On further investigating the role of HIV-1 Tat in Wnt/ $\beta$ catenin signaling via miRNA inhibition, it was found that Tat inhibits the activity of $\beta$-catenin in a miRNA 


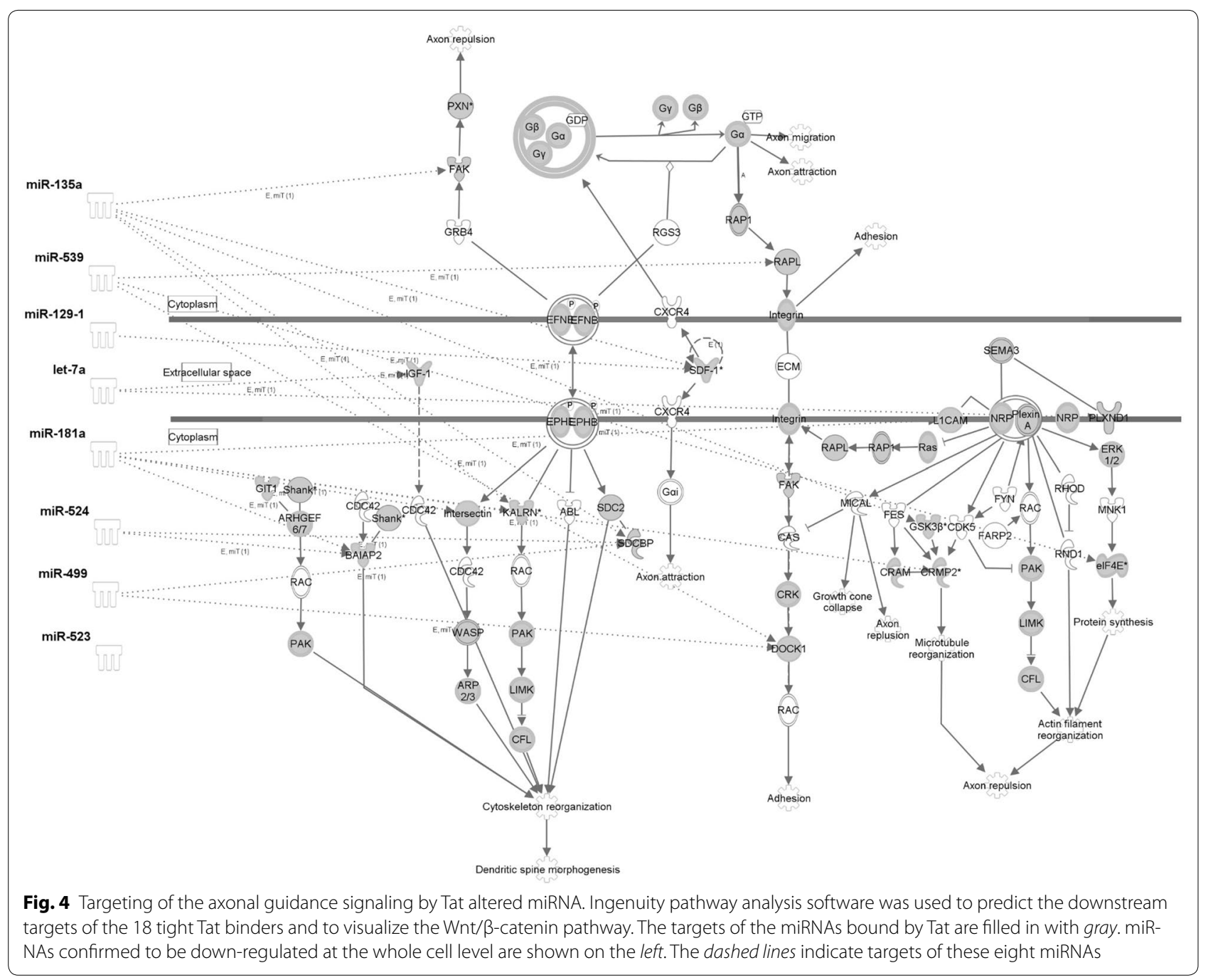

dependent manner. From previous studies, it has been noted that repression of $\beta$-catenin has a role to play in the neuropathogenesis of HIV. Here, we report that HIV-1 Tat indirectly inhibits the $\beta$-catenin activity via miRNA inhibition and this alteration of miRNA likely has a significant role to play in the neuropathogenesis of HAND in HIV-1 infected patients.

Our findings highlight the importance of the lysine residues at both position 41 and 51 of Tat. The K41A mutant and K51A mutant have previously been shown to have different effects: loss of transactivation ability and loss of Dicer inhibition respectively. That both motifs are required for efficient suppression of $\beta$-catenin activity is of interest. Additional work must be performed to expand our understanding of the mechanisms by which these motifs inhibit $\beta$-catenin. Additionally, other pathways involved in the pathogenesis of HAND that might be affected by alterations in miRNA must be evaluated. Previous studies have shown that opiate drugs like morphine exacerbate the neuropathogenesis in the CNS. This opens the intriguing possibility that opiates and Tat alter similar miRNA subsets. Continued examinations of the alterations of miRNAs, as well as the downstream effects of such alterations, could open up pathways to possible miRNA directed therapies or biomarkers for the diagnosis of HAND.

\section{Methods}

\section{Cell culture and transfection}

HEK 293T and HeLa were cultured in Dulbecco's Modified Eagle Medium and U-87MG were cultured in Eagles Minimal Essential Media, supplemented with 10 \% Fetal bovine serum, $4.5 \mathrm{~g} / \mathrm{l}$ of L-glutamine and penicillin/streptomycin. Cells were grown in $75 \mathrm{~cm}^{2}$ polystyrene flask under standard conditions at $37{ }^{\circ} \mathrm{C}$ with $5 \% \mathrm{CO}_{2}$. WTTat, K41A-Tat, K51A-Tat and CMV-GFP expression vectors were transfected into HEK $293 \mathrm{~T}$ cells in $9.60 \mathrm{~cm}^{2}$ wells with TransFectin Lipid Reagent (Bio-Rad, Hercules, 


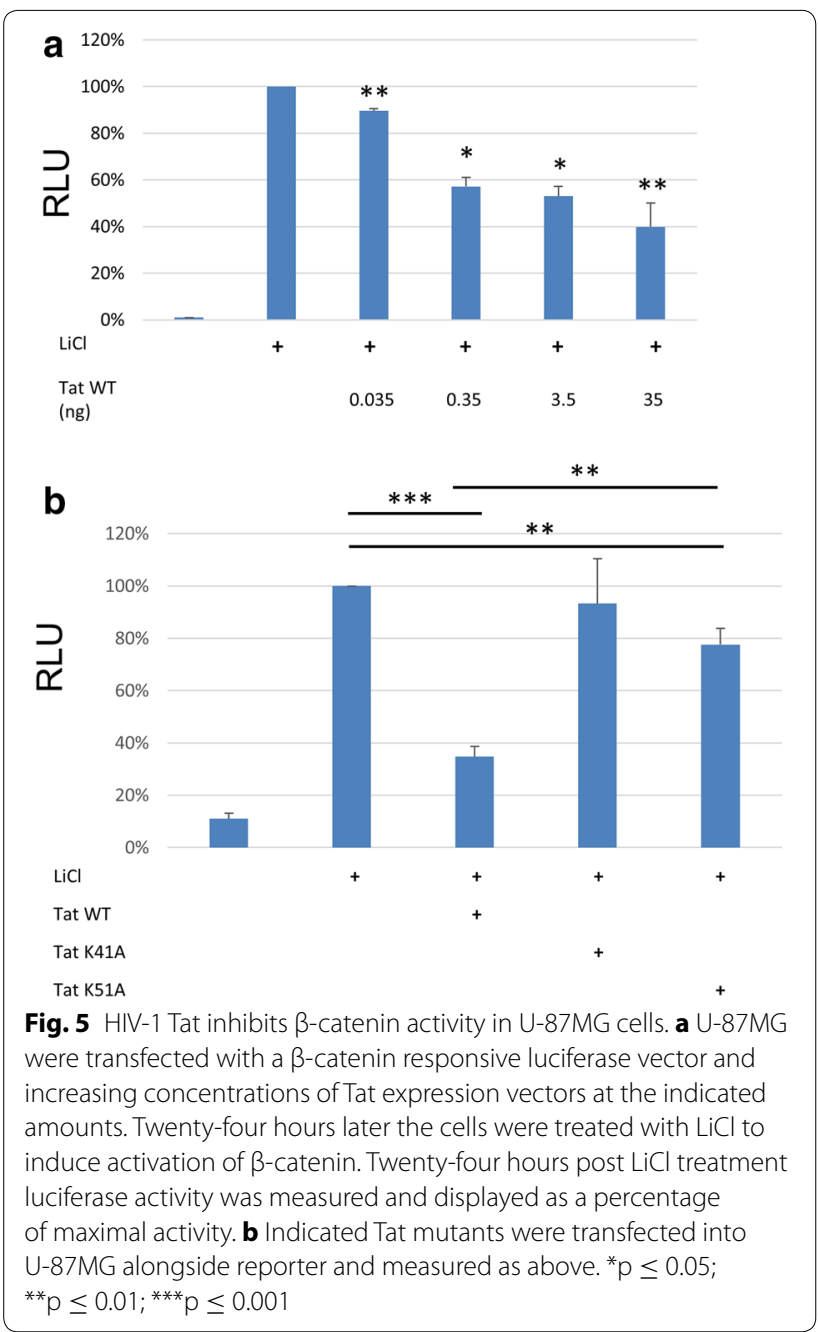

CA, USA). Cells were harvested after $48 \mathrm{~h}$ post-transfection, centrifuged for $2 \mathrm{~min}$ at $1500 \mathrm{rpm}$, washed 2 times with ice-cold phosphate buffered saline (PBS), lysed with $50 \mu$ RIPA buffer [( $150 \mathrm{mM} \mathrm{NaCl}, 1 \% \mathrm{NP}-40,0.5 \%$ sodium deoxycholate, $0.1 \%$ SDS, $50 \mathrm{mM}$ Tris ( $\mathrm{pH}$ 8.0)] and put on ice for $30 \mathrm{~min}$. Cell suspensions were centrifuged for $5 \mathrm{~min}$ at 14,000 rpm and supernatants were stored at $20{ }^{\circ} \mathrm{C}$ for further analysis. For the luciferase assay, U-87MG and HeLa were cultured in 96-well plate and transfected with TransFectin Lipid Reagent (Bio-Rad, Hercules, CA, USA). miRNA inhibitors were obtained from GE Dharmacon (Miridian miRNA inhibitors).

\section{Co-immunoprecipitation}

Co-IP was performed using the Pierce classic IP kit. In brief, $1 \mathrm{mg}$ cell lysate from each transfected sample was prepared with IP lysis buffer. Cell lysate $(1 \mathrm{mg})$ was added to Pierce Spin Column, containing $80 \mu \mathrm{l}$ of the Control Agarose Resin Slurry and incubated at $4{ }^{\circ} \mathrm{C}$ for $1 \mathrm{~h}$ on a rocker. The binding of antibody to protein was facilitated by addition of $2 \mu \mathrm{g}$ of monoclonal anti-Flag antibody (ThermoFisher Scientific, monoclonal clone L5) to tubes containing pre-cleared cell lysate. The tubes were incubated at $4{ }^{\circ} \mathrm{C}$ overnight with constant shaking. The prepared Pierce Protein A/G Agarose beads were added to the antibody-protein solution and incubated for $1 \mathrm{~h}$ at $4{ }^{\circ} \mathrm{C}$ with constant shaking. The antibody-proteinagarose bead solution was centrifuged in a $1.5 \mathrm{ml}$ collection tube (ThermoFisher Scientific, Rockford, IL, USA) at $1000 \mathrm{~g}$ for $1 \mathrm{~min}$. The supernatant was discarded and the pellet was placed in a new collection tube. The pellet was washed three times with Pierce IP Lysis/Wash Buffer and finally with $100 \mu \mathrm{l}$ of $1 \times$ conditioning buffer (diluted from 100× ThermoFisher Scientific Conditioning Buffer). The immune complex (antibody-protein-agarose bead) was eluted by addition of $500 \mu \mathrm{l}$ of Trizol Reagent (Invitrogen, Carlsbad, CA, USA) to the Pierce spin column.

\section{RNA extraction and RT-PCR}

The homogenized immune complex in Trizol obtained from Co-IP was incubated for $5 \mathrm{~min}$ at room temperature and centrifuged at $1000 \mathrm{~g}$ for $1 \mathrm{~min}$ to obtain the dissociated nucleoprotein complex in a new collection tube. The elution was followed by addition of $100 \mu \mathrm{l}$ of chloroform for phase separation as per the manufacturer's protocol (Invitrogen, Carlsbad, CA, USA). In order to precipitate RNA from aqueous phase, $250 \mu \mathrm{l}$ of $100 \%$ isopropanol was used. The pellet was washed with $500 \mu \mathrm{l}$ of $75 \%$ ethanol and centrifuged at $7500 \mathrm{~g}$ for $5 \mathrm{~min}$ at $4{ }^{\circ} \mathrm{C}$. Total RNA was resuspended in $40 \mu \mathrm{l}$ of RNase-free water (5 Prime, Hilden, Germany) and incubated at $60{ }^{\circ} \mathrm{C}$ for $15 \mathrm{~min}$. The total yield of isolated RNA was determined using NanoDrop (ThermoFisher Scientifc, Rockford, IL, USA). RNA extraction was repeated in a similar manner with $100 \mu \mathrm{g}$ of whole cell lysates $89.5 \mathrm{ng}$ of total RNA was used to measure miRNA using the QuantiMiR RT Kit (System Biosciences).

\section{Real-time qPCR and miRNA profiling}

Real-time PCR was carried out using System Biosciences miRNome miRNA Profilers QuantiMir Kit (System Biosciences, Mountain View, CA, USA) following the company protocol. Analysis was limited to the first plate in the microRNome array, which contains the most commonly studied miRNAs. Previous studies have shown that this method allows the detection of both pre-miRNA and mature miRNA $[41,42]$.

\section{Luciferase activity}

$\beta$-Catenin activity was measured by transfection of cells with TCF-LEF Reporter system (SABiosciences). To activated $\beta$-catenin, cells were treated with either 10 or 


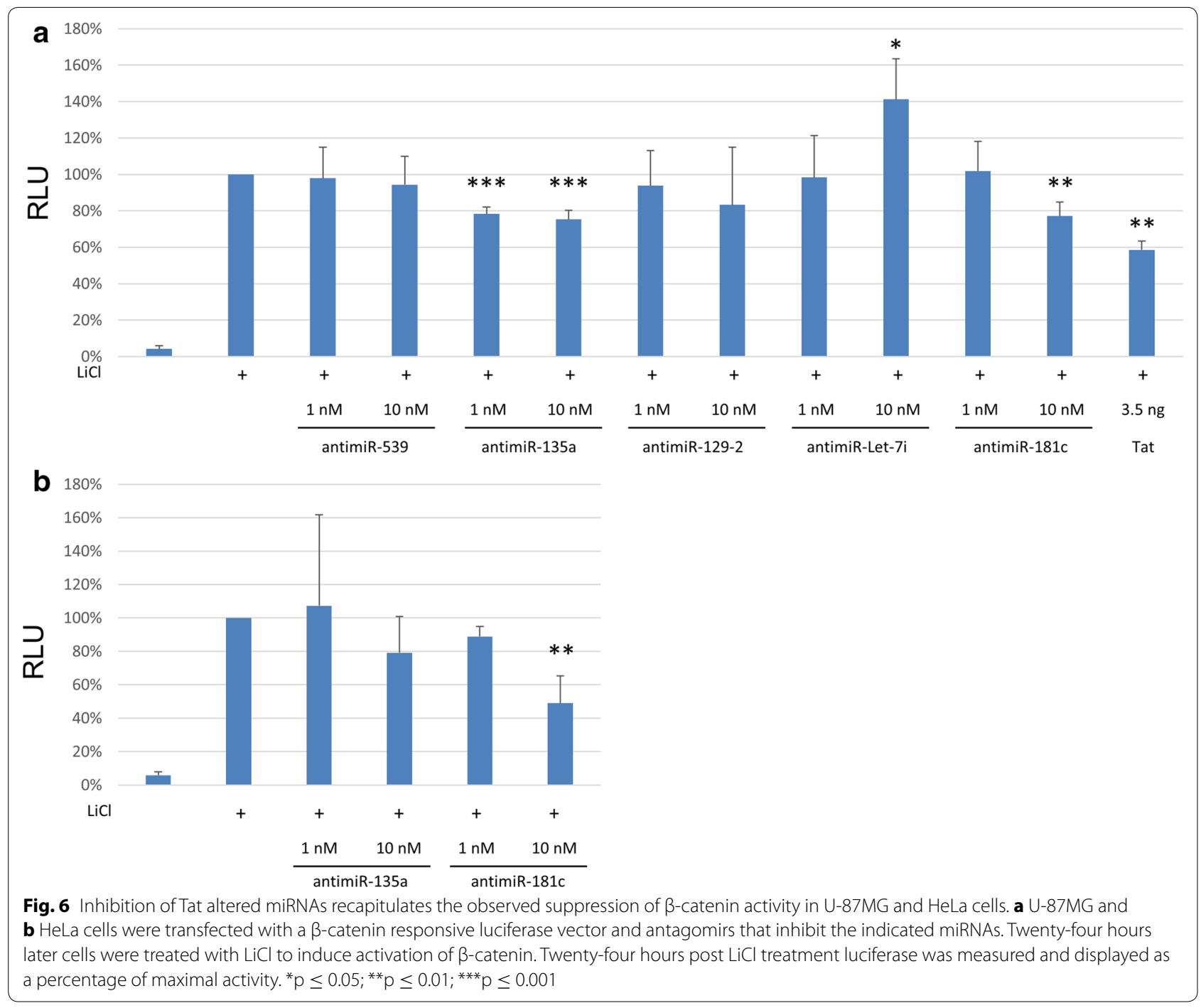

$50 \mathrm{mM} \mathrm{LiCl}$. $\beta$-catenin responsive luciferase levels were measured using the Dual-Glo ${ }^{\circledR}$ Luciferase Assay System (Promega). Firefly luciferase responsive to beta-catenin was normalized to renilla luciferase internal control.

\section{Additional file}

Additional file 1: Figure S1. HIV-1 Tat reverses morphological changes induced by LiCl in U-87MG. U-87MG were transfected with a CMV-GFP vector and Tat expression vector. $24 \mathrm{~h}$ later the cells were treated with $\mathrm{LiCl}$ to induce activation of $\beta$-catenin. Twenty-four hours post LiCl treatment cells were imaged both by bright field (top row) and fluorescence (bottom row) to identify cells that had successfully been transfected with the GFP and Tat vectors.

\section{Authors' contributions}

LS performed reporter cell assays, designed and performed the miRNA inhibitor studies and aided in writing the manuscript. PV performed the miRNA PCR analysis and assisted in writing manuscript, writing the manuscript, WE performed the microscopy and reporter cell assays, AE supported the cell culture and reporter assay work, ZK designed the studies, aided in the execution and helped write the manuscript. All authors read and approved the final manuscript.

\section{Acknowledgements}

This work was funded by University of the Sciences research funds awarded to ZK and NIH/NIDA 1R03DA039733-01 awarded to ZK.

Received: 18 August 2015 Accepted: 23 March 2016

Published online: 08 April 2016

\section{References}

1. Navia BA, Rostasy K. The AIDS dementia complex: clinical and basic neuroscience with implications for novel molecular therapies. Neurotox Res. 2005;8(1-2):3-24.

2. Neuenburg JK, Brodt HR, Herndier BG, Bickel M, Bacchetti P, Price RW, et al. HIV-related neuropathology, 1985-1999: rising prevalence of HIV encephalopathy in the era of highly active antiretroviral therapy. J Acquir Immune Defic Syndr. 2002;31(2):171-7. 
3. Chang HC, Samaniego F, Nair BC, Buonaguro L, Ensoli B. HIV-1 Tat protein exits from cells via a leaderless secretory pathway and binds to extracellular matrix-associated heparan sulfate proteoglycans through its basic region. AIDS. 1997;11(12):1421-31.

4. Chirmule N, Than S, Khan SA, Pahwa S. Human immunodeficiency virus Tat induces functional unresponsiveness in T cells. J Virol. 1995;69(1):492-8.

5. Ensoli B, Buonaguro L, Barillari G, Fiorelli V, Gendelman R, Morgan RA, et al. Release, uptake, and effects of extracellular human immunodeficiency virus type 1 Tat protein on cell growth and viral transactivation. J Virol. 1993;67(1):277-87.

6. Tardieu M, Hery C, Peudenier S, Boespflug O, Montagnier L. Human immunodeficiency virus type 1-infected monocytic cells can destroy human neural cells after cell-to-cell adhesion. Ann Neurol. 1992;32(1):117. doi:10.1002/ana.410320104.

7. Cass WA, Harned ME, Peters LE, Nath A, Maragos WF. HIV-1 protein Tat potentiation of methamphetamine-induced decreases in evoked overflow of dopamine in the striatum of the rat. Brain Res. 2003;984(1-2):133-42.

8. Hayman M, Arbuthnott G, Harkiss G, Brace H, Filippi P, Philippon V, et al. Neurotoxicity of peptide analogues of the transactivating protein tat from maedi-visna virus and human immunodeficiency virus. Neuroscience. 1993;53(1):1-6.

9. Turchan J, Pocernich CB, Gairola C, Chauhan A, Schifitto G, Butterfield DA, et al. Oxidative stress in HIV demented patients and protection ex vivo with novel antioxidants. Neurology. 2003;60(2):307-14.

10. Turchan-Cholewo J, Liu Y, Gartner S, Reid R, Jie C, Peng X, et al. Increased vulnerability of ApoE4 neurons to HIV proteins and opiates: protection by diosgenin and I-deprenyl. Neurobiol Dis. 2006;23(1):109-19. doi:10.1016/j. nbd.2006.02.005.

11. Sacktor N, Nakasujja N, Skolasky RL, Rezapour M, Robertson K, Musisi S, et al. HIV subtype D is associated with dementia, compared with subtype A, in immunosuppressed individuals at risk of cognitive impairment in Kampala, Uganda. Clin Infect Dis. 2009;49(5):780-6. doi:10.1086/605284.

12. Ranga U, Shankarappa R, Siddappa NB, Ramakrishna L, Nagendran R, Mahalingam $M$, et al. Tat protein of human immunodeficiency virus type 1 subtype C strains is a defective chemokine. J Virol. 2004;78(5):2586-90.

13. Paul RH, Joska JA, Woods C, Seedat S, Engelbrecht S, Hoare J, et al. Impact of the HIV Tat C30C31S dicysteine substitution on neuropsychological function in patients with clade C disease. J Neurovirol. 2014;20(6):627-35. doi:10.1007/s13365-014-0293-z.

14. Ferris MJ, Frederick-Duus D, Fadel J, Mactutus CF, Booze RM. The human immunodeficiency virus-1-associated protein, Tat1-86, impairs dopamine transporters and interacts with cocaine to reduce nerve terminal function: a no-net-flux microdialysis study. Neuroscience. 2009;159(4):1292-9. doi:10.1016/j.neuroscience.2009.01.024.

15. Yao H, Buch S. Rodent models of HAND and drug abuse: exogenous administration of viral protein(s) and cocaine. J Neuroimmune Pharmacol. 2012;7(2):341-51. doi:10.1007/s11481-012-9355-2.

16. Zhu J, Mactutus CF, Wallace DR, Booze RM. HIV-1 Tat protein-induced rapid and reversible decrease in $[3 \mathrm{H}]$ dopamine uptake: dissociation of $[3 \mathrm{H}]$ dopamine uptake and $[3 \mathrm{H}] 2$ beta-carbomethoxy-3-beta-(4-fluorophenyl)tropane (WIN 35,428) binding in rat striatal synaptosomes. J Pharmacol Exp Ther. 2009;329(3):1071-83. doi:10.1124/jpet.108.150144.

17. Anthony IC, Arango JC, Stephens B, Simmonds P, Bell JE. The effects of illicit drugs on the HIV infected brain. Front Biosci. 2008;13:1294-307.

18. Gurwell JA, Nath A, Sun Q, Zhang J, Martin KM, Chen Y, et al. Synergistic neurotoxicity of opioids and human immunodeficiency virus-1 Tat protein in striatal neurons in vitro. Neuroscience. 2001;102(3):555-63.

19. Hauser KF, El-Hage N, Stiene-Martin A, Maragos WF, Nath A, Persidsky Y, et al. HIV-1 neuropathogenesis: glial mechanisms revealed through substance abuse. J Neurochem. 2007;100(3):567-86. doi:10.1111/j.1471-4159.2006.04227.x.

20. Agrawal N, Dasaradhi PV, Mohmmed A, Malhotra P, Bhatnagar RK, Mukherjee SK. RNA interference: biology, mechanism, and applications. Microbiol Mol Biol Rev. 2003;67(4):657-85.
21. Bartel DP. MicroRNAs: genomics, biogenesis, mechanism, and function. Cell. 2004;116(2):281-97.

22. Hannon GJ. RNA interference. Nature. 2002;418(6894):244-51.

23. Bernstein E, Caudy AA, Hammond SM, Hannon GJ. Role for a bidentate ribonuclease in the initiation step of RNA interference. Nature. 2001;409(6818):363-6.

24. Cullen BR. Transcription and processing of human microRNA precursors. Mol Cell. 2004;16(6):861-5.

25. Gregory RI, Yan KP, Amuthan G, Chendrimada T, Doratotaj B, Cooch N, et al. The microprocessor complex mediates the genesis of microRNAs. Nature. 2004;432(7014):235-40.

26. Lee Y, Ahn C, Han J, Choi H, Kim J, Yim J, et al. The nuclear RNase III Drosha initiates microRNA processing. Nature. 2003;425(6956):415-9.

27. Sigova A, Rhind N, Zamore PD. A single Argonaute protein mediates both transcriptional and posttranscriptional silencing in Schizosaccharomyces pombe. Genes Dev. 2004;18(19):2359-67.

28. Sontheimer EJ. Assembly and function of RNA silencing complexes. Nat Rev Mol Cell Biol. 2005;6(2):127-38.

29. Olsen $\mathrm{PH}, \mathrm{Ambros} \mathrm{V}$. The lin-4 regulatory RNA controls developmental timing in Caenorhabditis elegans by blocking LIN-14 protein synthesis after the initiation of translation. Dev Biol. 1999;216(2):671-80.

30. Doench JG, Sharp PA. Specificity of microRNA target selection in translational repression. Genes Dev. 2004;18(5):504-11.

31. Haasnoot J, de Vries W, Geutjes EJ, Prins M, de Haan P, Berkhout B. The Ebola virus VP35 protein is a suppressor of RNA silencing. PLoS Pathog. 2007;3(6):e86. doi:10.1371/journal.ppat.0030086.

32. Bennasser Y, Le SY, Benkirane M, Jeang KT. Evidence that HIV-1 encodes an siRNA and a suppressor of RNA silencing. Immunity. 2005;22(5):607-19.

33. Bennasser Y, Jeang KT. HIV-1 Tat interaction with Dicer: requirement for RNA. Retrovirology. 2006;3:95. doi:10.1186/1742-4690-3-95.

34. Henderson LJ, Sharma A, Monaco MC, Major EO, Al-Harthi L. Human immunodeficiency virus type 1 (HIV-1) transactivator of transcription through its intact core and cysteine-rich domains inhibits Wnt/betacatenin signaling in astrocytes: relevance to HIV neuropathogenesis. J Neurosci. 2012;32(46):16306-13. doi:10.1523/JNEUROSCI.3145-12.2012.

35. Narasipura SD, Henderson LJ, Fu SW, Chen L, Kashanchi F, Al-Harthi L. Role of beta-catenin and TCF/LEF family members in transcriptional activity of HIV in astrocytes. J Virol. 2012;86(4):1911-21. doi:10.1128/JVI.06266-11.

36. Zhou L, Pupo GM, Gupta P, Liu B, Tran SL, Rahme R, et al. A parallel genome-wide mRNA and microRNA profiling of the frontal cortex of HIV patients with and without HIV-associated dementia shows the role of axon guidance and downstream pathways in HIV-mediated neurodegeneration. BMC Genomics. 2012;13:677. doi:10.1186/1471-2164-13-677.

37. Darbinian N, Darbinyan A, Czernik M, Peruzzi F, Khalili K, Reiss K, et al. HIV-1 Tat inhibits NGF-induced Egr-1 transcriptional activity and consequent p35 expression in neural cells. J Cell Physiol. 2008;216(1):128-34. doi:10.1002/jcp.21382.

38. Al-Harthi L. Interplay between Wnt/beta-catenin signaling and HIV: virologic and biologic consequences in the CNS. J Neuroimmune Pharmacol. 2012;7(4):731-9. doi:10.1007/s11481-012-9411-y.

39. Kino T, Kopp JB, Chrousos GP. Glucocorticoids suppress human immunodeficiency virus type-1 long terminal repeat activity in a cell type-specific, glucocorticoid receptor-mediated fashion: direct protective effects at variance with clinical phenomenology. J Steroid Biochem Mol Biol. 2000;75(4-5):283-90.

40. Jones GJ, Barsby NL, Cohen EA, Holden J, Harris K, Dickie P, et al. HIV-1 Vpr causes neuronal apoptosis and in vivo neurodegeneration. J Neurosci. 2007;27(14):3703-11. doi:10.1523/JNEUROSCI.5522-06.2007.

41. Coley W, Van Duyne R, Carpio L, Guendel I, Kehn-Hall K, Chevalier S, et al. Absence of DICER in monocytes and its regulation by HIV-1. J Biol Chem. 2010;285(42):31930-43. doi:10.1074/jbc.M110.101709.

42. Klase ZA, Houzet $L$, Jeang KT. Quantification of miRNA by poly(A)-RTqPCR arrays and verification of target sites in HIV-1 using a one-LTR infectious molecular clone. Methods Mol Biol. 2014;1087:285-96. doi:10.1007/978-1-62703-670-2_23. 